\title{
Effects of Biosurfactants on Gas Hydrates
}

\author{
Amit Arora1, Swaranjit Singh Cameotra ${ }^{2 *}$, Rajnish Kumar ${ }^{3}$, Pushpendra Kumar ${ }^{4}$, Chandrajit Balomajumder ${ }^{1}$ \\ ${ }^{1}$ Department of Chemical Engineering, Indian Institute of Technology, Roorkee, India \\ ${ }^{2}$ Institute of Microbial Technology, Chandigarh, India \\ ${ }^{3}$ Chemical Engineering and Process Development Division, National Chemical Laboratory, Pune, India \\ ${ }^{4}$ Keshav Dev Malviya Institute of Petroleum Exploration, Oil and Natural Gas Corporation (ONGC), Dehradun, India
}

\begin{abstract}
The increasing demand of fossil fuels resources and their continuous consumption has created a necessity for exploring the alternative resources of energy like gas hydrates. Gas hydrates exist under oceans and in permafrost regions. They are also known as methane hydrates or methane clathrates. These are stable at high pressure and low temperature. These are formed when methane gas comes in contact with sediments saturated with water. Pseudomonas aeruginosa and Bacillus subtilis were found in gas hydrates samples investigations from Gulf of Mexico and these microbes generated biosurfactants like Rhamnolipid and Surfactin. The current paper reports the effects of biosurfactants such as Rhamnolipid, Surfactin, Snomax, Emulsan, Phospholipids, Hydroxystearic acid etc. on Gas Hydrate formation.
\end{abstract}

Keywords: Gas hydrates; Rhamnolipid; Surfactin; Snomax; Emulsan; Hydroxystearic acid; Phospholipid

\section{Introduction}

Gas hydrates belong to a class of inclusion compounds and are known as clathrates. In these class of compounds host molecules like water encapsulates the guest molecules like methane, ethane, propane, $\mathrm{CO}_{2}$ etc. and forms a molecular cage. In these types of compounds only intermingling of molecules takes place and there is no chemical reaction occurs as such. Water molecules form hydrogen bonding and forms a polyhedral cavity and the guest molecules occupies the void.

The $\mathrm{CO}_{2}$ sequestration can help in releasing the methane captured in gas hydrates below the sea floors. The amount of energy released when $\mathrm{CO}_{2}$ gas hydrates gets formed is more than the amount of energy required to dissociate methane gas hydrates, $\mathrm{So}, \mathrm{CO}_{2}$ sequestration in gas hydrates can achieve two objectives at one time i.e. it can reduce the global warming and give the energy [1].

The gas hydrate reserves around the globe have organic carbon contained in them almost double than the amount contained in all fossil fuels on Earth as shown in Figure 1.

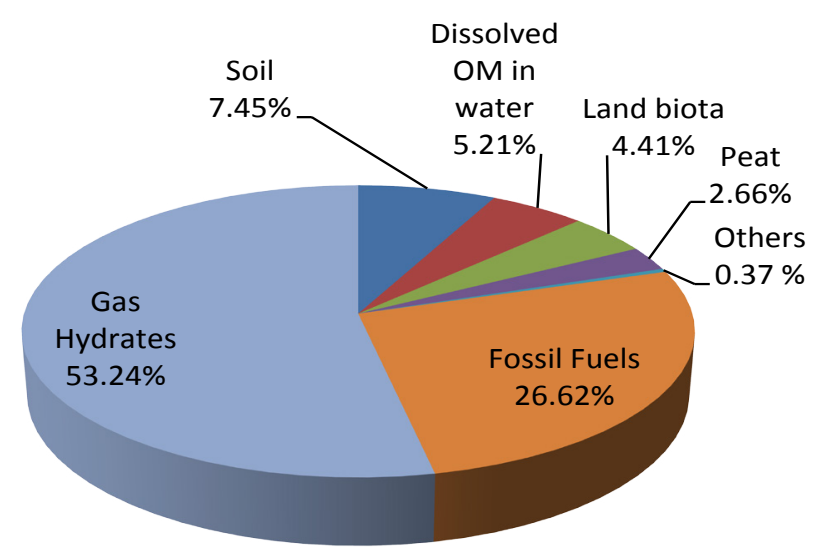

Figure 1: Distribution of organic carbon on Earth (Total 18,777 Gt) [2], Gt = Giga tonne.

\section{Molecular Structure}

The common structure formed by gas hydrates is structure I which is formed by gases like methane and molecules like propane, natural gas form structure II.

The Structure I consist of 2 small cages made up by 12 pentagonal surfaces called " 5 " and 6 larger cages of again 12 pentagonal and two hexagonal surfaces called $5^{12} 6^{2}[3]$. [4].

The unit cell consists of water molecules $=\left(12 \times 5^{12}+2 \times 5^{12} 6^{2}=46\right)$

Structure II consist of 16 small cages made up by 12 pentagonal surfaces called " 5 "12" and 8 larger cages of again 12 pentagonal and four hexagonal surfaces called $5^{12} 6^{4}[3]$.

The unit cell consists of water molecules $=\left(16 \times 5^{12}+8 \times 5^{12} 6^{4}=136\right)$ [4].

The hydrate cavities of structure I and structure II as shown in Figure 2.

For methane hydrate in structure I complete filling of both the large $\left(5^{12} 6^{2}\right)$ and small $\left(5^{12}\right)$ cavities by methane molecules will give hydrate i.e. $\mathrm{CH}_{4} \cdot 5.75 \mathrm{H}_{2} \mathrm{O}$. However complete filling of occupancy is not possible which leads to a hydrate ratio of around 1:6 (i.e. $\mathrm{CH}_{4} \cdot 6 \mathrm{H}_{2} \mathrm{O}$ ), which is equivalent to $96 \%$ cage occupancy [5,6], based on this $1 \mathrm{~m}^{3}$ of methane gas hydrate can occupy $167 \mathrm{~m}^{3}$ of methane at STP.

\section{Physical Properties of Gas Hydrates}

Gas Hydrates are non-stoichiometric compounds Gas Hydrates

*Corresponding author: Swaranjit Singh Cameotra, Senior Principa Scientist, Institute of Microbial Technology, Sector 39A, Chandigarh -160036, India, Tel: +91-9041036750; E-mail: ssc@imtech.res.in

Received March 14, 2014; Accepted April 17, 2014; Published April 25, 2014

Citation: Arora A, Cameotra SS, Kumar R, Kumar P, Balomajumder C (2014) Effects of Biosurfactants on Gas Hydrates. J Pet Environ Biotechnol 5: 170. doi:10.4172/2157-7463.1000170

Copyright: $(2014$ Arora A, et al. This is an open-access article distributed under the terms of the Creative Commons Attribution License, which permits unrestricted use, distribution, and reproduction in any medium, provided the original author and source are credited. 


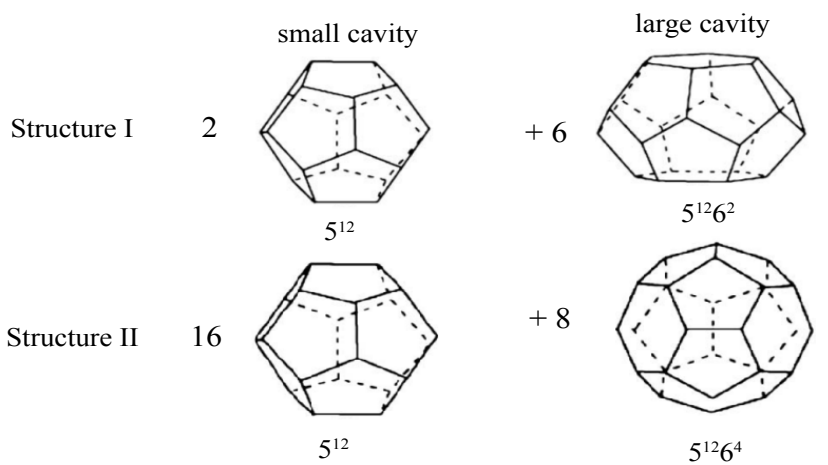

Figure 2: Hydrate cavities for structure I and structure II [4].

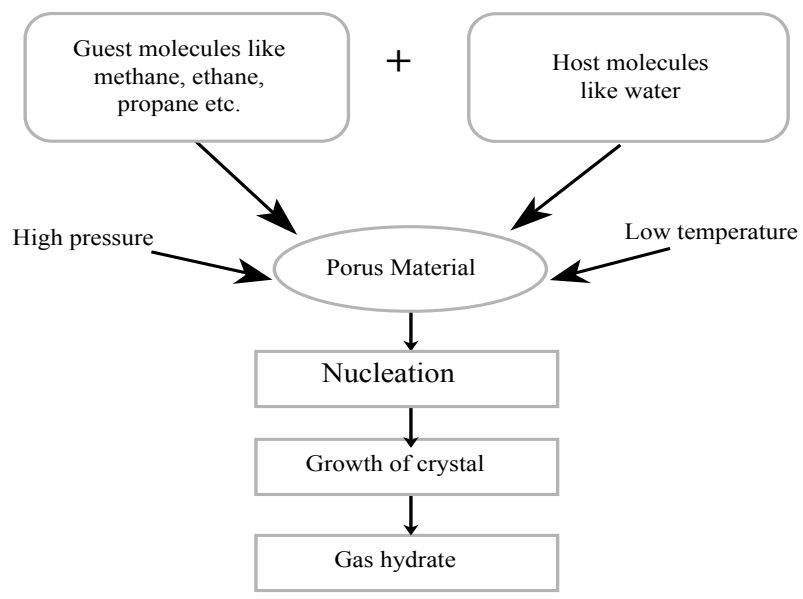

Figure 3: Mechanism of formation of Gas Hydrates.

are also known as crystalline form of Natural Gas. Physically natural Gas Hydrate is like white crystalline substance which can burn hence it is also known as burning ice. These types of molecules are formed under natural conditions of low temperature and high pressure. In gas hydrates the guest molecules are not physically bonded with the water lattice instead they are held through weak Van der Waals interactions.

\section{Occurrence of gas hydrates}

\section{Global scenario}

The occurrence of Gas Hydrate has been known since the mid of 1960's when they were discovered in Russia. They have been also discovered in permafrost regions, but mostly they occur in oceanic sediments below the sea floor where the depths are greater than about $500 \mathrm{~m}$. Gas Hydrates are detected at lesser depths also. These are present in oceanic sediments along continental margins as well as in polar continental settings [7]. Gas Hydrates are scattered from South Eastern coast of United States on the Black Ridge, in the Gulf of Mexico, western and eastern margins of Japan, the Middle America Trench and in the Cascadian Basin near Oregon, Peru. The worldwide occurrence of Gas Hydrate is shown in Figure 4.

\section{Indian scenario}

The gas hydrates are present in the K-G basin, Mahanadi Offshore
Basin and Andaman regions. Though gas hydrates have not been recovered from the drill site in the KK basin, various geo-scientific investigations indicate gas hydrates may be present in the Saurashtra and KK basins in western India margins [9]. The richest gas hydrate deposits $(\sim 130$ meter thick with $\sim 70 \%$ saturation and $60 \%$ porous fractured shale) are in the K-G basin and the thickest (260-600 meters) in Andaman sea (Figure 5).

\section{Energy Potential of Gas Hydrates}

Among all renewable (Solar, Wind, Wave, Nuclear, Hydro, Geothermal, Bioprocess etc.) and non-conventional (Gas Shale, Coal Bed Methane, Basin Centred Gas, Tight Gas Shale, Gas Hydrates etc.) energy resources, Gas Hydrates are regarded as one of the most suitable candidates for cleaner energy resources in this century. As per the USA department of energy, if only $1 \%$ of the methane stored in these

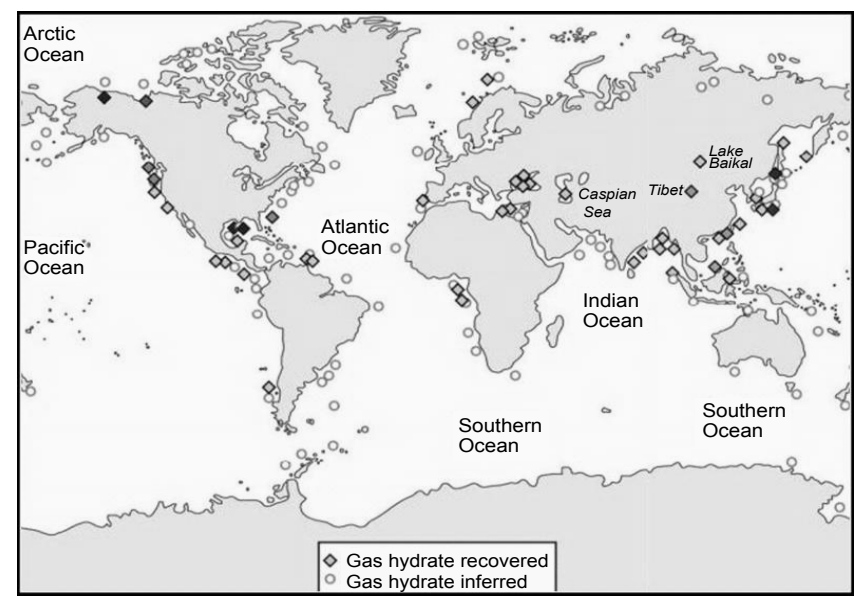

Figure 4: Distribution of known Gas Hydrate reserves throughout the world [8].

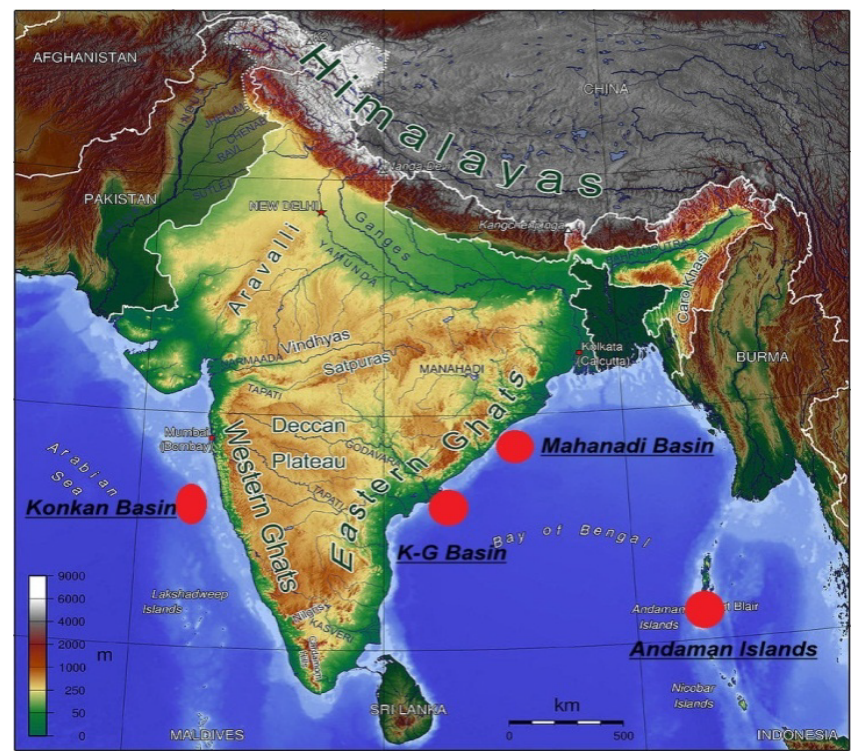

Figure 5: Overview map showing the locations of sites for Gas Hydrate coring/drilling in India [10] 


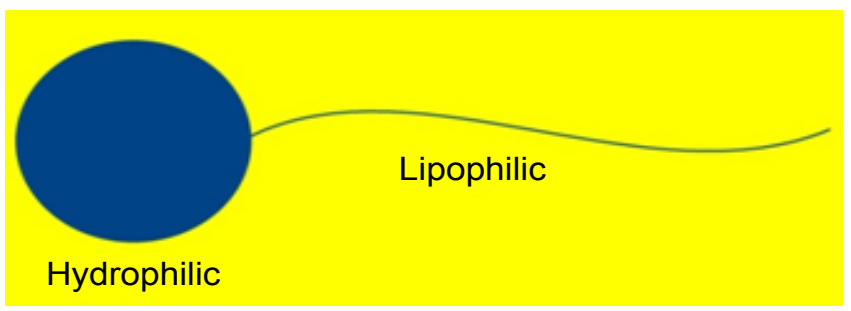

Figure 6: Structure of Biosurfactant.

\begin{tabular}{|c|c|c|c|c|}
\hline S.No. & Biosurfactant Type & Biosurfactant & Microorganism & Reference \\
\hline \multirow{5}{*}{1.} & \multirow{5}{*}{ Glycolipids } & Rhamnolipids & Pseudomonas aeruginosa, Pseudomonas chlororaphis & [21] \\
\hline & & Diglycosyl diglycerides & Lactobacillus fermentum & [22] \\
\hline & & Trehalose mycolates & $\begin{array}{l}\text { Rhodococcus erythropolis, Arthrobacter paraffineu, } \\
\text { Mycobacterium phlei, Nocardia erythropolis }\end{array}$ & [23] \\
\hline & & Sophorolipids & $\begin{array}{c}\text { Candida bombicola, C. antartica, } \\
\text { Torulopsis petrophilum C. botistae, } \\
\text { C. apicola, C. riodocensis, C. stellata, C. bogoriensis }\end{array}$ & [24] \\
\hline & & Aminoacids lipids & Bacillus sp. & [25] \\
\hline \multirow{2}{*}{2.} & \multirow{2}{*}{$\begin{array}{l}\text { Phospholipid and Fatty } \\
\text { acids }\end{array}$} & Fatty acids/neutral lipids & $\begin{array}{c}\text { Clavibacter } \\
\text { michiganensis subsp. Insidiosus }\end{array}$ & [26] \\
\hline & & Phospholipids & Acinetobacter sp. & [27] \\
\hline \multirow{7}{*}{3.} & \multirow{7}{*}{$\begin{array}{l}\text { Lipopeptides and } \\
\text { lipoproteins }\end{array}$} & Peptide lipids & Bacillus licheniformis & [28] \\
\hline & & Serrawettin & Serratia marcescens & [29] \\
\hline & & Ornithine lipid & Pseudomonas sp, Thiobacillust hiooxidans & [20] \\
\hline & & Viscosin & $\begin{array}{l}\text { Pseudomonas fluorescens, } \\
\text { Leuconostoc mesenteriods }\end{array}$ & [30] \\
\hline & & Surfactin & Bacillus subtilis & [31] \\
\hline & & Subtilisin & Bacillus subtilis & [32] \\
\hline & & Lichenysin & Bacillus licheniformis, Bacillus subtilis & [33] \\
\hline \multirow{5}{*}{4.} & \multirow{5}{*}{ Polymeric Surfactant } & Protein PA & Pseudomonas aeruginosa & [34] \\
\hline & & Liposan & Candida lipolytica & [35] \\
\hline & & Lipoheteropolysaccharide (Emulsan) & $\begin{array}{c}\text { Acinetobacter calcoaceticus RAG-1, Arethrobacter } \\
\text { calcoaceticus }\end{array}$ & [36] \\
\hline & & Polysaccharide-lipid complex (Snomax) & Pseudomonas syringae & [37] \\
\hline & & Alasan & A. radio resistens & [38] \\
\hline \multirow{2}{*}{5.} & \multirow{2}{*}{ Particulate biosurfactants } & Whole cells & cyanobacteria & [39] \\
\hline & & Vesicles & Acinetobacter sp. & [20] \\
\hline
\end{tabular}

Table 1: Various types of Biosurfactants produced by Microorganisms.

Hydrates could be recovered, it would be more than double the current domestic supply of Natural Gas [11,12].

\section{Role of Microbes in Gas Hydrates}

Actually high porosity of Methane Gas Hydrate with pore sizes of $100-400 \mathrm{~nm}$ and pore volumes of $25-40 \%$ [13] allows potential substrate eg. sulphate to enter and products of microbial metabolism eg. sulphite to exit the gas hydrate structure without difficulty. The microbe community is active with the Gas Hydrates.

Bacillus subtilis and Pseudomonas aeruginosa are identified in Gulf of Mexico gas hydrate mounds [14]. These microbes produce Surfactin and Rhamnolipid biosurfactants respectively.

The above generated biosurfactants i.e. Surfactin and Rhamnolipid reduce the surface tension of water and produce carbon alkyl group chains which form spherical micelles that solubilize hydrocarbon gases [15]. Water associates around the periphery of the micelles in close proximity to the solubilized gas. Thus micelles act as nucleation site for hydrate crystals to grow.

\section{Biosurfactants}

Biosurfactants are amphiphilic molecules (water loving and fat loving) consisting of a hydrophilic and a hydrophobic domain. Usually the hydrophobic domain is a hydrocarbon whereas the hydrophilic domain can be non-ionic positively or negatively charged or amphoteric $[16,17]$ which is shown in Figure 6.

Biosurfactants have a unique property of lowering the surface and interfacial tension and Critical Micelles Concentration (CMC) in both aqueous solution and hydrocarbon mixtures [18,19]. CMC is the threshold concentration of a surfactant to form micelles. A good surfactant can lower the surface tension of water from 72 to $35 \mathrm{mN} / \mathrm{m}$. Generally biosurfactants are more efficient and their CMC is about 1040 times lower than that of chemical surfactants, i.e. less surfactant is necessary to get a maximum decrease in surface tension [20].

\section{Microorganisms producing biosurfactants}

Biosurfactants produced by microorganisms mainly bacteria, fungi and yeasts are diverse in chemical composition. The nature 
<smiles>CCCCCCCC(CC(=O)O)OC(=O)CC(CCCCCCC)OC1OC(C)C(O)C(O)C1O</smiles>

Figure 7a: Structure of Monorhamnolipid: Rha- $\mathrm{C}_{10}-\mathrm{C}_{10}$.

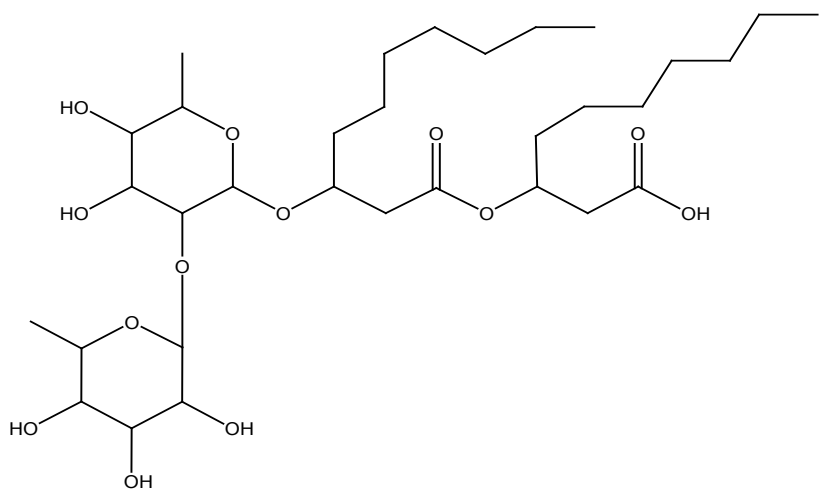

Figure 7b: Structure of Dirhamnolipid: Rha-Rha- $C_{10}-C_{10}$

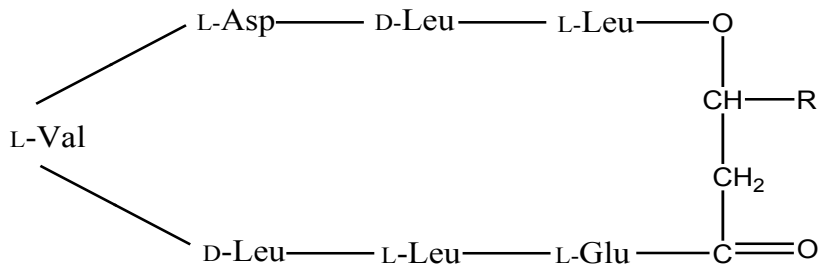

Figure 8a: Structure of Surfactin.

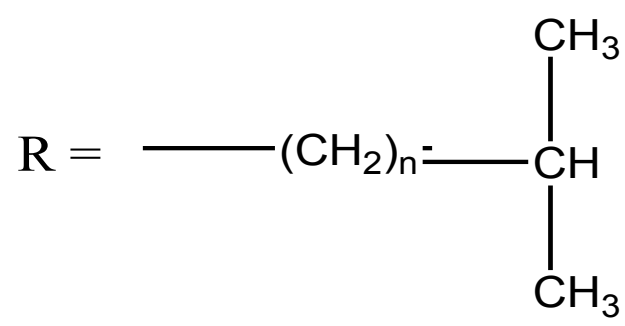

Figure 8b: Lipid chains of Surfactin Molecule.

and the amount of biosurfactant produced depend on the type of microorganism producing it. Biosurfactants can be classified as: (1) Glycolipids, (2) Phospholipid and Fatty acids. (3) Lipopeptides and lipoproteins, (4) Polymeric surfactant and (5) Particulate biosurfactants the various biosurfactants along with the micro-organisms producing them is as shown in table 1.

\section{Types of Biosurfactants}

\section{Glycolipids}

Rhamnolipid: Rhamnolipids are produced by Pseudomonas aeruginosa. They have a glycosyl head group, a Rhamnose moiety, and a 3-(hydroxyalkanoyloxy) alkanoic acid (HAA) fatty acid tail. Mono-rhamnolipids and di-Rhamnolipids are two main classes of rhamnolipids; consisting of one or two Rhamnose groups respectively. Rhamnolipids are also heterogeneous in the length and degree of branching of the HAA moiety which varies with the growth media used and the environmental conditions. Rhamnolipids have much lower CMC than even Sodium dodecyl Sulphate $[26,40,41]$; and they can be adsorbed on sediment particle surfaces $[18,26]$. Micelles can migrate through porous media if micelle diameter is less than about $50 \mathrm{~nm}$ $[26,42]$. Rhamnolipid micelles is of the order of $5 \mathrm{~nm}$ diameter [43]; whereas SDS micelles are more accurately reported as spheres with 33.4 nm diameter [15], hence it can easily migrate through porous media. In the analysis of sand associated with the gas hydrates from Gulf of Mexico [14], the Pseudomonas aeruginosa bacterium was identified which generated Rhamnolipid. The structure of Rhamnolipid is shown in Figure $7 \mathrm{a}$ and $7 \mathrm{~b}$.

\section{Lipopeptides and lipoproteins}

Surfactin: Surfactin is lipopeptide formed from Bacillus subtilis bacterium. It is a lipopeptide that is composed of one $\beta$-hydroxy fatty acid, which has a long fatty acid moiety, and seven amino acids. It can lower the surface tension of water from 72 to $27 \mathrm{mN} / \mathrm{m}$. [44]. It is named surfactin due to its exceptional surfactant activity [45].

Bacillus subtilis bacterium was identified in the analysis of sand associated with gas hydrates in the Gulf of Mexico [14], which generated surfactin.

The Structure of Surfactin is shown in Figure $8 \mathrm{a}$ and $8 \mathrm{~b}$

(where ' $n$ ' can vary for various Surfactin Molecules as 7,8,9,10)

Various types of amino acids present in a Surfactin is as given in Table 2.

\section{Phospholipid and fatty acids}

Phospholipids: Phospholipids are a class of lipids and can form lipid bilayers, they are a major component of all cell membranes. Phospholipids generally contain a phosphate group, diglyceride, and a simple organic molecule such as choline. The structure of the phospholipid molecule consists of a hydrophilic head and a hydrophobic tails. Phospholipids provide membrane fluidity and mechanical strength in eukaryotic cells. There are three types of phospholipids that are synthetically derived as described below.

Phosphocholines (DMPC): DMPC has a chemical name as 1,2-Dimyristoyl-sn-glycero-3-phosphocholine. Its empirical formula is $\mathrm{C}_{36} \mathrm{H}_{72} \mathrm{NO}_{8} \mathrm{P}$ and has a molecular weight 677.93 . The structure of DMPC is as shown in Figure 9.

\begin{tabular}{|c|c|c|c|c|}
\hline S.No & Letter & Name of Amino Acid & $\begin{array}{c}\text { Molecular } \\
\text { Formula }\end{array}$ & $\begin{array}{c}\text { Mass } \\
\text { (g/mol) }\end{array}$ \\
\hline 1. & Val & Valine & $\mathrm{C}_{5} \mathrm{H}_{11} \mathrm{NO}_{2}$ & 117.151 \\
\hline 2. & Asp & Aspartic acid & $\mathrm{C}_{4} \mathrm{H}_{7} \mathrm{NO}_{4}$ & 133.11 \\
\hline 3. & Leu & Leucine & $\mathrm{C}_{6} \mathrm{H}_{13} \mathrm{NO}_{2}$ & 131.17 \\
\hline 4. & Glu & Glutamic acid & $\mathrm{C}_{5} \mathrm{H}_{9} \mathrm{NO}_{4}$ & 147.13 \\
\hline \multicolumn{5}{|r}{ Table 2: Amino Acids found in Surfactin. } \\
\hline \multicolumn{2}{|r}{}
\end{tabular}




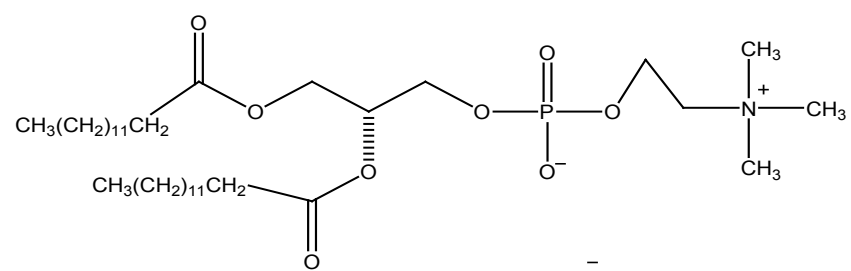

Figure 9: Structure of DMPC.

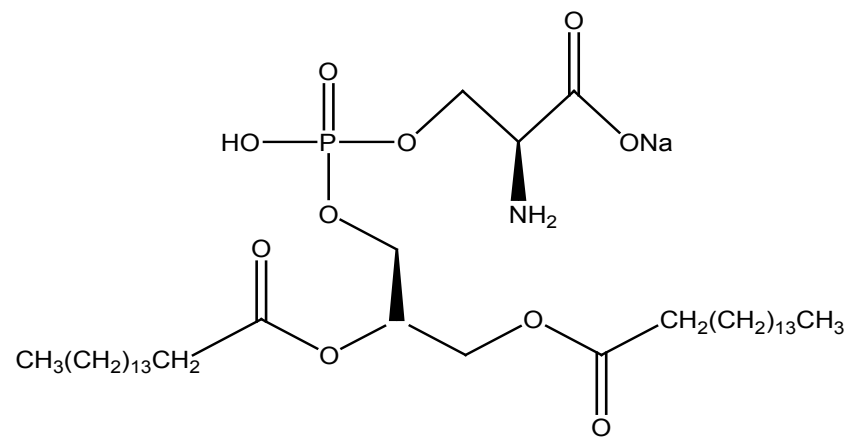

Figure 10: Structure of DPPS.

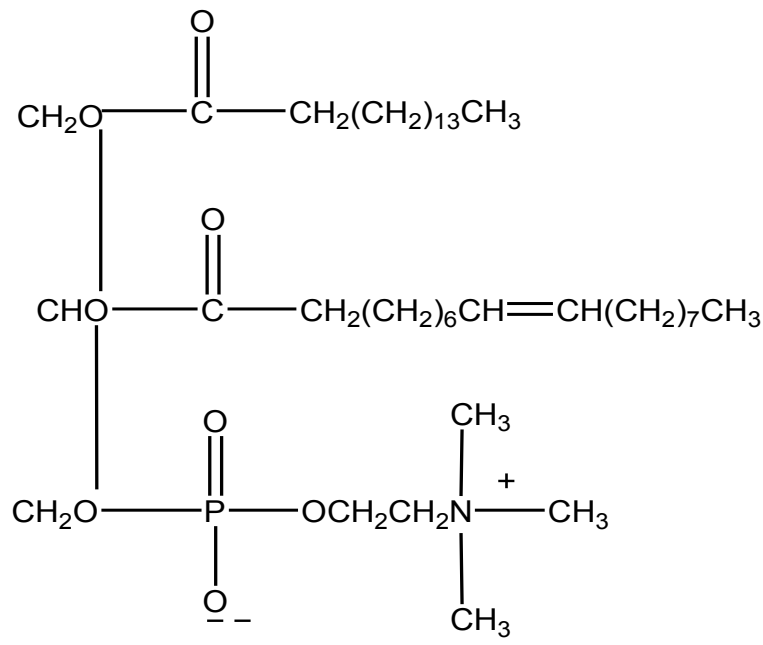

Figure 11: Structure of POPC.

Phosphoserines (DPPS): DPPS has a chemical name as 1, 2 Dipalmitoyl-sn-glycero-3-phospho-L-serine sodium salt. Its empirical formula is $\mathrm{C}_{38} \mathrm{H}_{73} \mathrm{NO}_{10} \mathrm{PNa}$ and has a molecular weight 757.95 The structure of DPPS is as shown in Figure 10.

Mixed Chain Phospholipids (POPC): POPC has a chemical name as 1-palmitoyl-2-oleoyl-sn-glycero-3-phosphocholine. It is available commercially and synthetically. It is also naturally present in eukaryoticcell membranes. Its empirical formula is $\mathrm{C}_{42} \mathrm{H}_{82} \mathrm{NO}_{8} \mathrm{P}$ and has a molecular weight 760.08. The structure of POPC is as shown in Figure 11.

\section{Polysaccharide-lipid complex}

Snomax: Snomax is produced by Pseudomonas syringae bacterium.
It has ice nucleation protein. It is a type of polysaccharide-lipid complex [46]. It contains $34 \%$ protein, $15 \%$ mono and disaccharides, and $11 \%$ nucleic acids [47].

Emulsan: Emulsan is a type of polysaccharide-lipid complex produced by Acinetobacter calcoaceticus bacterium. The molecular weight of Emulsan is 89,000 [48]. Emulsan does not form micelles; however, its hydrophobic-hydrophilic moieties could serve to unite the water and the host hydrocarbon to promote hydrate formation.

\section{Hydroxylated fatty acid}

DL-a-Hydroxystearic acid: It is a synthetic fatty acid and has chemical name as DL- $\alpha$-Hydroxystearic acid (2-Hydroxyoctadecanoic Acid) $\mathrm{C}_{18} \mathrm{H}_{36} \mathrm{O}_{3}$, has a molecular weight 300.48. DL- $\alpha$ Hydroxystearic Acid is a mixture of D and L-a-hydroxystearic Acid (2-Hydroxyoctadecanoic Acid) enantiomers. It has surface properties similar to corynocycolic fatty acids [49]. The structure of Hydroxystearic acid is as shown in Figure 12.

\section{Relationship between Gas Hydrates and Biosurfactants}

The Biosurfactants influence the induction time and rate of formation of Gas Hydrate. The induction time is the time elapsed til the appearance of a detectable volume of hydrate phase or until the consumption of a detectable number of moles of hydrate former gas. The induction time is also termed the hydrate nucleation time.

The kinetics of gas hydrate formation has been studied with biosurfactants in laboratory. It is reported that Rhamnolipids has much lower CMC than SDS (sodium dodecyl sulphate) [41,42]. Biosurfactant increase the rate of formation of gas hydrates above the CMC of the surfactant [50]. The surfactin is a powerful biosurfactant which can reduce the surface tension of water to as low as $27 \mathrm{mN} / \mathrm{m}$. [42]. Biosurfactants catalyze gas hydrate formation in sea beds by following ways: (1) They reduce induction time of gas hydrate formation, (2) They increase formation rate of gas hydrate, (3) They solubilize guest gases in micelles that migrate through sands to a hydrate zone. The effects of Biosurfactants on Gas Hydrates kinetics is as shown in Table 3.

As it is evident from the above Table 3, that the biosurfactants increase the Hydrate formation rate and decrease the hydrate induction time. Surfactin has increased the hydrate formation rate by $288 \%$, which is the highest amongst the all biosurfactant. Reduction in Hydrate induction rate was also found maximum in surfactin. DL-AHydroxy-stearic acid ${ }^{* *}$ is the only biosurfactant which decreased the hydrate formation rate instead of increasing. This could be due to fact that the fatty acid solution must have covered the wetted porous mediagas interface which could have resulted in low permeability for the diffusion of gas which resulted into the decrease in hydrate formation rate, which is exception amongst all.

\section{Production technologies}

Thenaturalgasfromgashydratecan beproducedviaDepressurization [55], Thermal stimulation [56], Chemical Inhibitor Injection [57], and

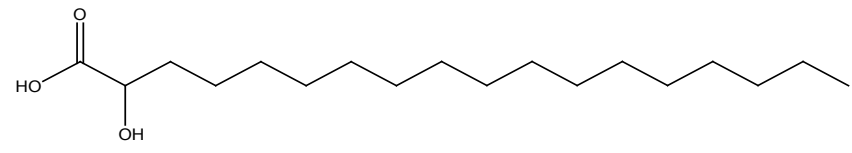

Figure 12: Structure of Hydroxystearic acid. 
Citation: Arora A, Cameotra SS, Kumar R, Kumar P, Balomajumder C (2014) Effects of Biosurfactants on Gas Hydrates. J Pet Environ Biotechnol 5: 170. doi:10.4172/2157-7463.1000170

Page 6 of 7

\begin{tabular}{|c|c|c|c|c|c|c|c|}
\hline \multirow[t]{2}{*}{ S.No } & \multirow[t]{2}{*}{ Micro-organism } & \multirow{2}{*}{\multicolumn{2}{|c|}{ Biosurfactant Produced }} & $\begin{array}{l}\text { Induction Time in } \\
\text { minute }\end{array}$ & \multirow{2}{*}{$\begin{array}{l}\text { Increase in Hydrate } \\
\text { formation rate }\end{array}$} & \multirow{2}{*}{$\begin{array}{l}\text { Reduction in hydrate } \\
\text { Induction time (approx.) }\end{array}$} & \multirow[t]{2}{*}{ Reference } \\
\hline & & & & (approx.) & & & \\
\hline 1 & $\begin{array}{l}\text { Pseudomonas } \\
\text { aeruginosa }\end{array}$ & \multicolumn{2}{|c|}{ Rhamnolipid } & 53 & $96 \%$ to $107 \%$ & $58 \%$ & {$[21,51-53]$} \\
\hline 2 & Bacillus subtilis & \multicolumn{2}{|c|}{ Surfactin } & 35 & $288 \%$ & $71 \%$ & {$[31,49,51-53]$} \\
\hline \multirow{3}{*}{3} & Thiobacillus species & \multirow{3}{*}{ Phospholipid } & 1. DPPS & 1. 67 & \multirow{3}{*}{$96 \%$ to $107 \%$} & 1. $47 \%$ & \multirow{3}{*}[27,51,53]{} \\
\hline & $\begin{array}{c}\text { Coryneba-cterium } \\
\text { species }\end{array}$ & & 2. POPC & 2. 90 & & 2. $28 \%$ & \\
\hline & & & 3. DMPC & 3. 100 & & 3. $20 \%$ & \\
\hline 4 & $\begin{array}{c}\text { Pseudomonas } \\
\text { syringae }\end{array}$ & \multicolumn{2}{|c|}{ Snomax } & 87 & $135 \%$ & $30 \%$ & {$[37,46,51-53]$} \\
\hline 5 & $\begin{array}{c}\text { Coryneba-cterium } \\
\text { lepus }\end{array}$ & \multicolumn{2}{|c|}{ DL-A-Hydroxy-stearic acid } & 56 & $49 \%$ ** & $58 \%$ & {$[49,51-53]$} \\
\hline 6 & $\begin{array}{l}\text { Acinetob-acter } \\
\text { calcoaceti-cus }\end{array}$ & \multicolumn{2}{|c|}{ Emulsan } & 75 & $135 \%$ & $40 \%$ & {$[36,51-53,54]$} \\
\hline
\end{tabular}

Table 3: Effects of various Biosurfactants on Gas Hydrate formation.

$\mathrm{CO}_{2}$ sequestration [58]. Among these, Depressurization and Thermal stimulation have been considered to be the most economical, though other methods are under investigation. Due to less energy input for Depressurization, this method has been studied more than the Thermal Stimulation. Chemical Inhibitor Injection is not economical as it includes the cost of chemicals and their puming. The efficiency of $\mathrm{CO}_{2}$ sequestration is also less and investigations are going on at laboratory scale to enhance the efficiency of this method as it is greener than any other method.

\section{Conclusion}

A huge amount of methane is captured in gas hydrates even a small percentage of this can meet the energy demands of today's world for centuries. If we are able to exploit this resource of energy then these could be substitute to the fossil fuel and will put an advantage over them as cleaner fuels. Even these can be exploited by using $\mathrm{CO}_{2}$ Sequestration which can give us the future energy resource by reducing the global warming. It was evident from the NGHP (National Gas Hydrate Program) expedition that the gas hydrates are distributed in the KrishnaGodavari, Mahanadi and Andaman off shores in Indian context. The Pseudomonas aeruginosa and Bacillus subtilis were found in the gas hydrate analyzed in the Gulf of Mexico which generated Rhamnolipid and Surfactin respectively. Hence there is a role of biosurfactants in the formation of gas hydrates in natural conditions. Long term production tests are planned in USA and Japan to establish the viability of efficient and long term production technologies. It is expected that the dream of taking energy from fire in the ice will be a reality very soon.

\section{References}

1. Ohgaki K, Takano K, Sangawa H, Matsubara T, Nakano S (1996) Methane exploitation by carbon dioxide from gas hydrates. Phase equilibria for $\mathrm{CO} 2 \mathrm{CH} 4$ mixed hydrate system. J Chem Eng Jpn 29: 478-483.

2. Kvenvolden KA (1993) Gas hydrates-geological perspective and global change. Rev Geophys 31: 173-187.

3. Sloan ED Jr (2003) Fundamental principles and applications of natural gas hydrates. Nature 426: 353-363.

4. Nindorf J (1996) Experimental and theoretical investigation of hydrate formation of natural gases under operating conditions. universität karlsruhe Germany.

5. Handa YP (1986) Compositions, enthalpies of dissociation, and heat capacities in the range 85 to $270 \mathrm{~K}$ for clathrate hydrates of methane, ethane, and propane, and enthalpy of dissociation of isobutane hydrate, as determined by a heat-flow calorimeter. The Journal of Chemical Thermodynamics 18: 915-921.

6. Rueff RM, Sloan ED, Yesavage VF (1988) Heat capacity and heat of dissociation of methane hydrates. AIChE J 34: 1468-1476.
7. Paull CK, Dillon WP (2001) Natural gas hydrates: occurrence, distribution, and detection. American Geophysical Union, Geophysical monograph 124.

8. Hester KC, Brewer PG (2009) Clathrate hydrates in nature. Ann Rev Mar Sci 1: 303-327.

9. Paropkari AL, Babu CP, Mascarenhas A (1993) New evidence for enhanced preservation of organic carbon in contact with oxygen minimum zone on the western continental slope of India. Mar Geol 111: 7-13.

10. Pushpendra K, Bhagwani SS, Dasgupta DK (2013) Gas Hydrate Exploratory Efforts in Indian Offshore. Proceedings of $3^{\text {rd }}$ Seminar on Petroliferous Basins of India. KDMIPE ONGC Dehradun March 1-2 ONGC bulletin 48: 65-76.

11. Holder GD, Malone RD, Lawson WF (1987) Effects of Gas Composition and Geothermal Properties on the Thickness and Depth of Natural-Gas-Hydrate Zones. J Petrol Technol 39: 147-152.

12. Haq BU (1998) Gas GSA Today. Geological society of America (GSA) Boulder CO. United states 8-11: 1-6.

13. Kuhs WF, Klapproth A, Gotthardt F, Techmer K, Heinrichs T (2000) The formation of meso- and macroporous gas hydrates. Geophys Res Lett 27 2929-2932.

14. Lanoil BD, Sassen R, La Duc MT, Sweet ST, Nealson KH (2001) Bacteria and Archaea physically associated with Gulf of Mexico gas hydrates. Appl Environ Microbiol 67: 5143-5153.

15. MacKerell Jr. AD (1995) Molecular Dynamics Simulation Analysis of a Sodium Dodecyl Sulfate Micelle in Aqueous Solution: Decreased Fluidity of the Micelle Hydrocarbon Interior. J Phys Chem 99: 1846-1855.

16. Georgiou G, Lin SC, Sharma MM (1992) Surface-active compounds from microorganisms. Biotechnology (N Y) 10: 60-65.

17. Desai AJ, Patel RM, Desai JD (1994) Advances in the production of biosurfactants and their commercial applications. Journal of Scientific and Industrial Research 53: 619-629.

18. Banat IM (1995) Biosurfactants production and possible uses in microbia enhanced oil recovery and oil pollution remediation: A review. Bioresource Technol 51: 1-12.

19. Rahman KS, Rahman TJ, McClean S, Marchant R, Banat IM (2002) Rhamnolipid biosurfactant production by strains of Pseudomonas aeruginosa using low-cost raw materials. Biotechnol Prog 18: 1277-1281.

20. Desai JD, Banat IM (1997) Microbial production of surfactants and their commercial potential. Microbiol Mol Biol Rev 61: 47-64.

21. Jadhav M, Kalme S, Tamboli D, Govindwar S (2011) Rhamnolipid from Pseudomonas desmolyticum NCIM-2112 and its role in the degradation of Brown 3REL. J Basic Microbiol 51: 385-396.

22. Mulligan CN, Yong RN, Gibbs BF (2001) Remediation technologies for metalcontaminated soils and groundwater: an evaluation. Eng Geol 60: 193-207.

23. Muthusamy K, Gopalakrishnan S, Ravi TK, Sivachidambaram P (2008) Biosurfactants: properties, commercial production and application. Curr Sci India 94: 736-774. 
Citation: Arora A, Cameotra SS, Kumar R, Kumar P, Balomajumder C (2014) Effects of Biosurfactants on Gas Hydrates. J Pet Environ Biotechnol 5: 170. doi:10.4172/2157-7463.1000170

24. Felse PA, Shah V, Chan J, Rao KJ, Gross RA (2007) Sophorolipid biosynthesis by Candida bombicola from industrial fatty acid residues. Enzyme Microb Tech 40: $316-323$

25. Cotter PD, Hill C, Ross RP (2005) Bacteriocins: developing innate immunity for food. Nat Rev Microbiol 3: 777-788.

26. Herman DC, Maier RM (2002) Biosynthesis and Applications of Glycolipid and LipopeptideBiosurfactants. In; Lipid Biotechnology. Kuo TM, Gardner HW Dekker M New York, USA 629-654.

27. Kosaric N (2001) Biosurfactants and Their Application for Soil Bioremediation. Food Technology and Biotechnology 39: 295-304.

28. Begley M, Cotter PD, Hill C, Ross RP (2009) Identification of a novel twopeptide lantibiotic, lichenicidin, following rational genome mining for LanM proteins. Appl Environ Microbiol 75: 5451-5460.

29. Lai CC, Huang YC, Wei YH, Chang JS (2009) Biosurfactant-enhanced removal of total petroleum hydrocarbons from contaminated soil. J Hazard Mater 167: 609-614.

30. Banat IM, Franzetti A, Gandolfi I, Bestetti G, Martinotti MG, et al. (2010) Microbial biosurfactants production, applications and future potential. Appl Microbiol Biotechnol 87: 427-444.

31. Arguelles-Arias A, Ongena M, Halimi B, Lara Y, Brans A, et al. (2009) Bacillus amyloliquefaciens GA1 as a source of potent antibiotics and other secondary metabolites for biocontrol of plant pathogens. Microb Cell Fact 8: 63.

32. Sutyak KE, Wirawan RE, Aroutcheva AA, Chikindas ML (2008) Isolation of the Bacillus subtilis antimicrobial peptide subtilosin from the dairy product-derived Bacillus amyloliquefaciens. J Appl Microbiol 104: 1067-1074.

33. Yakimov MM, Amro MM, Bock M, Boseker K, Fredrickson HL, et al. (1997) The potential of Bacillus licheniformis strains for in situ enhanced oil recovery. J Petrol Sci Eng 18: 147-160.

34. Hisatsuka K, Nakahara T, Sano T, Yamada K (1971) Formation of Rhamnolipid by Pseudomonas aeruginosa; its fermentation in hydrocarbon fermentations. Agr Biol Chem Tokyo 35: 686-692.

35. Cirigliano MC, Carman GM (1984) Isolation of a bioemulsifier from Candida lipolytica. Appl Environ Microbiol 48: 747-750.

36. Choi JW, Choi HG, Lee WH (1996) Effects of ethanol and phosphate on emulsan production by Acinetobacter calcoaceticus RAG-1. J Biotechnol 45: 217-225.

37. Skirvin RM, Kohler E, Steiner H, Ayers D, Laughnan A, et al. (2000) The use of genetically engineered bacteria to control frost on strawberries and potatoes. Whatever happened to all of that research? Sci Hortic-Amsterdam 84: 179-189.

38. Barkay T, Navon-Venezia S, Ron EZ, Rosenberg E (1999) Enhancement of solubilization and biodegradation of polyaromatic hydrocarbons by the bioemulsifier alasan. Appl Environ Microbiol 65: 2697-2702.

39. Levy N, Bar-Or Y, Magdassi S (1990) Flocculation of bentonite particles by a cyanobacterial bioflocculant. Colloid Surface 48: 337-349.

40. Thangamani S, Shreve GS (1994) Effect of anionic biosurfactant on hexadecane partitioning in multiphase systems. Environ Sci Technol 28: 1993-2000.
41. Churchill SA, Griffin RA, Jones LP, Churchill PF (1995) Biodegradation Rate Enhancement of Hydrocarbons by an Oleophilic Fertilizer and a Rhamnolipid Biosurfactant. J Environ Qual 24: 19-28.

42. Bai G, Brusseau ML, Miller RM (1997) Influence of a Rhamnolipid Biosurfactant on the Transport of Bacteria through a Sandy Soil. Appl Environ Microbiol 63 : 1866-1873.

43. Champion JT, Gilkey JC, Lamparski H, Retterer J, Miller RM (1995) Electron Microscopy of Rhamnolipid (Biosurfactant) Morphology: Effects of $\mathrm{pH}$ Cadmium, and Octadecane. J Colloid Interf Sci 170: 569-574.

44. Nakano MM1, Marahiel MA, Zuber P (1988) Identification of a genetic locus required for biosynthesis of the lipopeptide antibiotic surfactin in Bacillus subtilis. J Bacteriol 170: 5662-5668.

45. Peypoux F, Bonmatin JM, Wallach J (1999) Recent trends in the biochemistry of surfactin. Appl Microbiol Biotechnol 51: 553-563.

46. Goodnow RA, Harrison MD, Morris JD, Sweeting KB, Laduca RJ (1990) Fate of Ice Nucleation-Active Pseudomonas syringae Strains in Alpine Soils and Waters and in Synthetic Snow Samples. Appl Environ Microbiol 56: 2223-2227.

47. Amende B, Gordon J (1999) Literature and analyses reports on Snomax. York Snow Inc. Victor, NY

48. Shoham Y, Rosenberg E (1983) Enzymatic depolymerization of emulsan. Bacteriol 156: 161-167.

49. Rosenberg E (1986) Microbial surfactants. CRC Crit Rev Microbiol 3: 109-132.

50. Z Zhong Y, Rogers RE (2000) Surfactant effects on gas hydrate formation. Chem Eng Sci 55: 4175-4187.

51. Karsa DR (1998) New Products and Applications in Surfactant Technology. Sheffield Annual Surfactants Review Blackwell UK.

52. Kosaric N (1992) Biosurfactants in industry. Pure \& Appl Chem 64: 1731-1737.

53. Rogers RE, Kothapalli C, Lee MS, Woolsey JR (2003) Catalysis of Gas Hydrates by Biosurfactants in Seawater-Saturated Sand/Clay. Can J Chem Eng 81: 973-980.

54. Rosenberg E (1993) Pan Award. Microbial diversity as a source of useful biopolymers. J Ind Microbiol 11: 131-137.

55. Moridis GJ, Collett TS, Dallimore SR, Satoh T, Hancock S, et al. (2004) Numerical studies of gas production from several $\mathrm{CH} 4$ hydrate zones at the Mallik site, Mackenzie Delta, Canada. J Petrol Sci Eng 43: 219-238.

56. Goel N, Wiggins M, Shah S (2001) Analytical modeling of gas recovery from in situ hydrates dissociation. J Petrol Sci Eng 29: 115-127.

57. Desa E (2001) Submarine Methane Hydrates Potential Fuel Resource of the 21st Century. Proc of AP Akademi of Sciences 5: 101-114.

58. Ohgaki K, Takano K, Moritoki M (1994) Exploitation of CH4 Hydrates under the Nankai Trough in Combination with CO2 Storage. Kagaku Kogaku Ronbunshu 20: $121-123$. 